\title{
THE 1909 NORTH CAROLINA DRAINAGE ACT AND AGRICULTURAL DRAINAGE EFFECTS IN EASTERN NORTH CAROLINA
}

\author{
MICHAEL A. O’DRISCOLL \\ Department of Geological Sciences, 204 Graham Building, East Carolina University, Greenville, NC 27858-4353
}

\begin{abstract}
Over the last two centuries, agricultural drainage in eastern North Carolina has transformed extensive wetlands to productive croplands. At the start of the drainage movement in the early 1900s, approximately 200,000 hectares (one half million acres) of drained agricultural lands existed in North Carolina. The 1909 North Carolina Drainage Act allowed for more extensive drainage projects. Drainage districts provided effective drainage outlets for farms and reduced flooding for the district. The districts dramatically increased the extent of drained lands during the $20^{\text {th }}$ century. Currently, it is estimated that over 2 million hectares (five million acres) of drained agricultural lands exist in North Carolina, with the majority in the Coastal Plain. Agricultural drainage has contributed to huge gains in agricultural productivity in the region. However, this drainage has contributed to regional stream water quality impairment, altered stream hydrology, and wetland conversion. Over the last three decades, much work has been focused on reducing watershed nutrient exports in eastern North Carolina. Several major strategies have been used to decrease the environmental impacts of agricultural drainage, including: agronomic management practices; controlled drainage; riparian and wetland buffers; and channel alterations. Management of agricultural drainage during the $21^{\text {st }}$ century will play a crucial role in regional stream, wetland, and coastal ecosystem health.
\end{abstract}

Key Words: Coastal Plain; Nutrients; Controlled Drainage; Agricultural Streams; Runoff.

\section{INTRODUCTION}

The history of agricultural drainage and its impacts on streams has been documented in the midwestern US (Fausey et al. 1995) and nationally (Pavelis 1987; Skaggs et al. 1994). Eastern North Carolina has an extensive history of agricultural drainage and is fringed by nutrient sensitive rivers, wetlands and estuaries, yet a regional assessment of the effects of agricultural drainage has not yet been conducted. There is a growing need for a better understanding of the history and evolution of agricultural drainage in the region. A growing body of evidence indicates that agricultural drainage in the region impacts surface water and groundwater hydrology. This paper documents the history and extent of agricultural drainage in eastern North Carolina, the effects of agricultural drainage on hydrology in the region and highlights some of the current and potential strategies to address the environmental impact of agricultural drainage on streams.

\section{HISTORY OF AGRICULTURAL DRAINAGE IN EASTERN NORTH CAROLINA}

The Coastal Plain comprises approximately 6.5 million hectares (16 million acres or approximately $44 \%$ of the state) and includes the Outer Coastal Plain (Tidewater) and the Inner Coastal Plain (Fig. 1). The Outer Coastal Plain consists of the low-lying coastal area where streams are affected by oceanic tides and is separated from the Inner Coastal Plain by the Suffolk Scarp. The Inner Coastal Plain lies between the Outer Coastal Plain and Piedmont regions and is characterized by greater elevations (than the Outer Coastal Plain), gently rolling hills, valleys, and flat inter-stream divides. Sea-level rise and fall linked with glacial and interglacial cycles has influenced transgressive and regressive sedimentation within the Coastal Plain. Inner Coastal Plain soils often consist of coarse marine, fluvial, and aeolian sediments with high infiltration capacities, although poorly drained marine sediments are also present (Winner and Coble 1996). Inner Coastal Plain soils are generally better drained and have less organic matter than those of the Outer Coastal Plain, where extensive peat formations exist (Tesoriero et al. 2004). The Inner Coastal Plain setting is dominated by forested land $(47 \%)$ and agricultural land (35\%), whereas the Outer Coastal Plain setting is dominated by wetlands (37\%), forested land (28\%), and agricultural land (26\%) (Tesoriero et al. 2004). The principal agriculture in the region includes corn, soybean, cotton, peanut, tobacco, grain, and potato cultivation and chicken, turkey, hog, and cattle production (Spruill et al. 1998). Although less than 5\% of the Coastal Plain consists of developed land (Spruill et al. 1998), recent urban growth in cities such as Greenville, Jacksonville, New Bern and Wilmington, has resulted in localized declines in agricultural land use (Hardison et al. 2009). For example, in the Tar River Basin between 1982 and 1997, urban land use has 


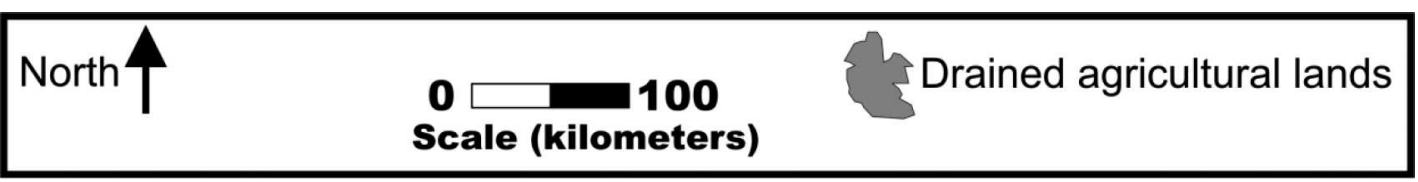

\section{0}
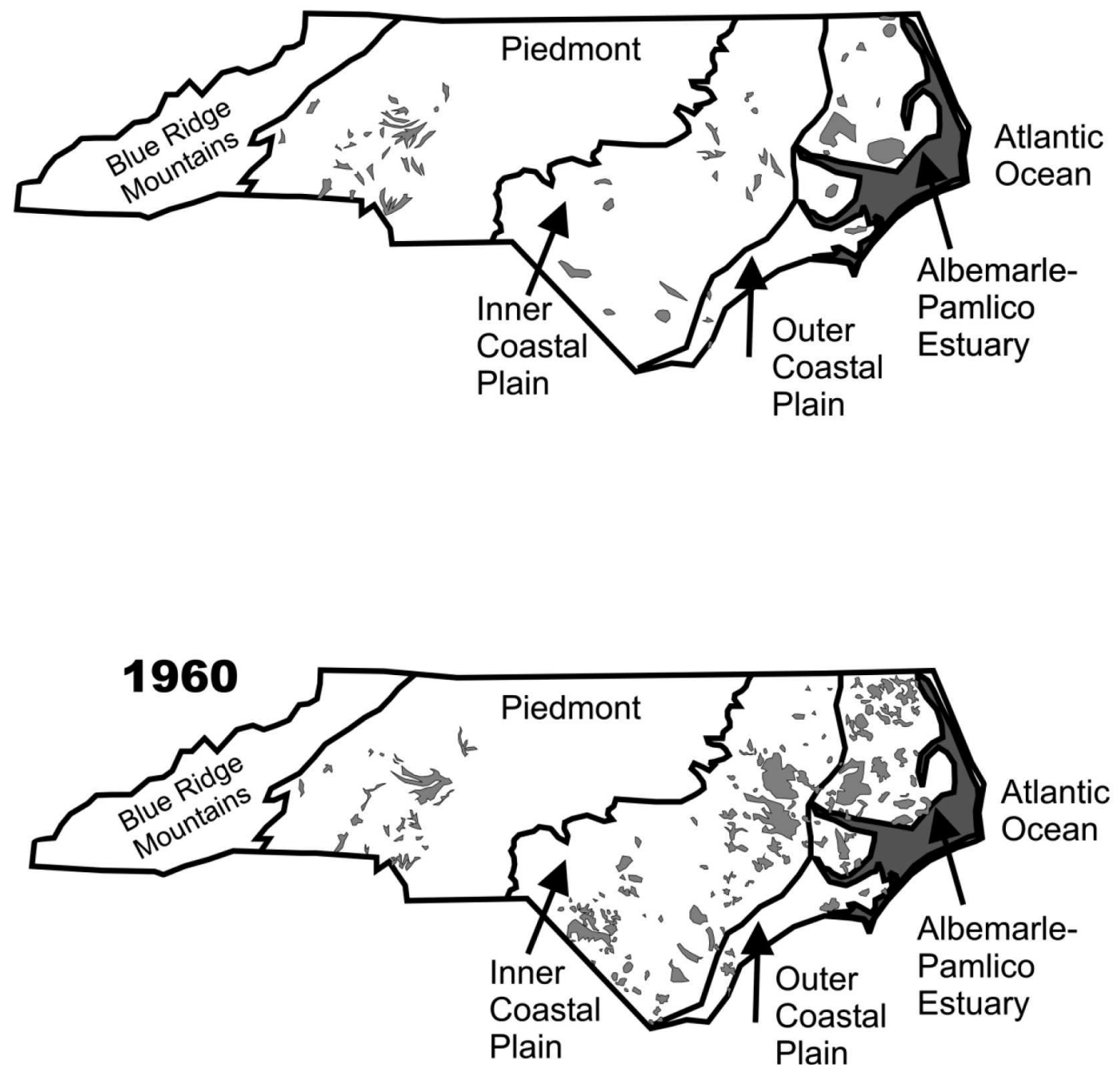

FIG. 1. The extent of drained agricultural lands in North Carolina in 1920 and 1960 (modified from US Bureau of Census 1922 and 1961 ).

increased by $90.1 \%$ and cultivated cropland has decreased by $16.6 \%$ (NCDENR 2004).

Unaltered Coastal Plain fluvial systems are characterized by low gradient streams with broad floodplains subject to frequent and often prolonged inundation (Hupp 2000). Stream discharge in the region is typically greatest in February and March and at a minimum in September-October (with the exception of tropical storm effects) (Winner and Simmons 1977; Williams and Pinder 1990). Generally, the streams are dominated by groundwater inputs (Spruill et al. 1998). Base flow in low-order streams usually ceases during the summer months when evapotranspiration draws down water tables below stream channels (e.g., Harden and Spruill 2008). A combination of warmer climate and lower hydraulic head gradients contributes to much larger losses of annual precipitation as evapotranspiration in the Coastal Plain (approximately 70\% of precipitation in North Carolina) than in other physiographic regions such as the Mountains (approximately $48 \%$ of precipitation) (Sun et al. 2002).

Abundant rainfall (approximately $125 \mathrm{~cm} / \mathrm{yr}$ of rainfall) (Boyles et al. 2004) across the relatively broad and flat Coastal Plain region results in extensive wetlands and floodplains. These characteristics have contributed to a rich history of agricultural drainage in 
eastern North Carolina. One of the earliest major drainage projects in the U.S. was undertaken by the Dismal Swamp Canal Company in eastern Virginia and North Carolina, chartered in 1778 (Beauchamp 1987). In the Lake Phelps and Lake Mattamuskeet regions, drainage activities began in the late 1700s. In the 1800s, North Carolina began to encourage drainage for agricultural and forestry operations (Lilly 1981). Edmund Ruffin (an agriculturalist and author), noted that the (then) current system of drainage ditches was not sufficient to drain Coastal Plain sites because of the shallow groundwater table. He performed a survey of eastern North Carolina which he presented to the Governor in 1861. Ruffin stated "the tilled land is but partially and insufficiently drained. On much the larger portion, perhaps nineteen-twentieths of all the cultivated and even highest surface of the whole region, the drainage is much worse and still more insufficient." He suggested it would be more effective to adapt the modern English system of drainage which would help lower water tables and reduce swampy conditions (Ruffin 1861). Ruffin also provided suggestions for plowing and maintaining artificially drained lands (Fig. 2).

Drainage activities in eastern North Carolina were limited up until the mid-1800s by what could be performed by manual labor, but the advances in clay and concrete tile drain manufacturing in the mid $1800 \mathrm{~s}$ and mechanical ditch diggers in the late 1800s provided opportunities to drain wetlands at a much faster pace than had been possible in earlier drainage projects (Beauchamp 1987). During the 1800s and early 1900s, it was generally believed that wetlands in eastern North Carolina were unsanitary and their drainage could: (1) improve the condition of the land and public health of the surrounding communities (Kerr 1875, Herritage 1920); (2) greatly enhance agricultural production (Pratt 1908); and (3) improve conditions for road construction and railroads, which would enhance commerce (Tatum 1910; Ross 1973). These and other descriptions of eastern North Carolina during the 1800s and early 1900s suggest a negative perception of the vast wetlands that existed in eastern North Carolina at the time. Sledge Tatum, a surveyor with the U.S. Geological Survey (USGS) described the Coastal Plain as "millions of acres of swamp lands which serve no useful purpose, but are a serious menace to the physical health of a large body of our population and interfere seriously with highway construction, which is necessary to social and business intercourse" (Tatum 1910).

Toward the end of the $19^{\text {th }}$ century, there was growing interest in drainage in eastern North Carolina. The state organized drainage districts in an effort to more efficiently drain the poorly-drained lands. The interest in public drainage projects had grown and the North Carolina Drainage Association was organized by the

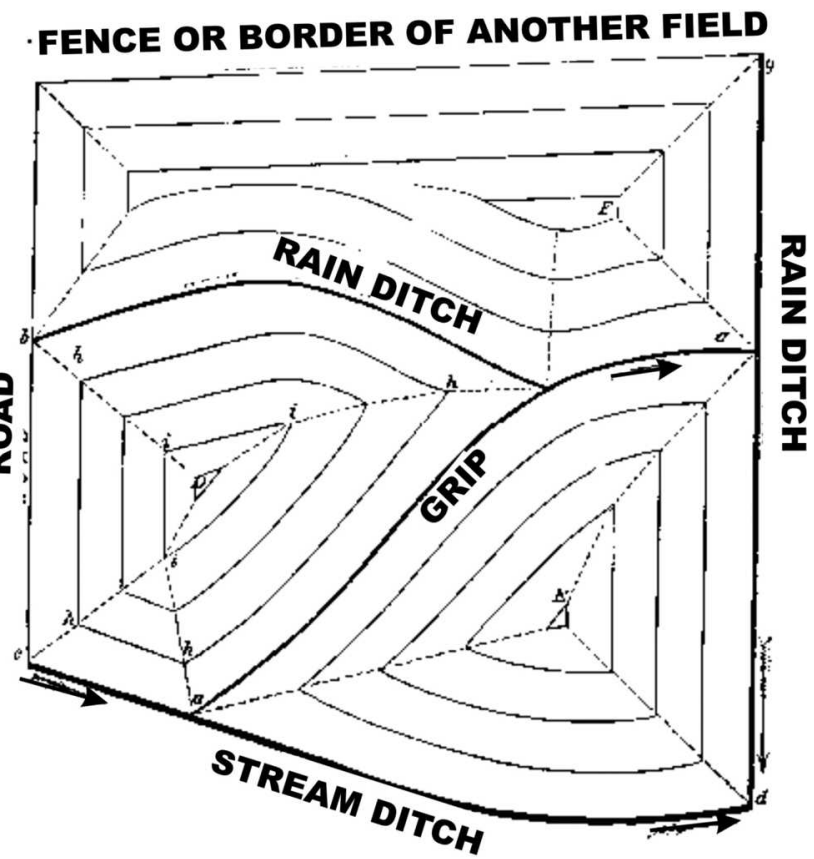

FIG. 2. Edmund Ruffin explored eastern North Carolina in the mid $1800 \mathrm{~s}$ and suggested draining the region to improve agricultural productivity and living conditions. This figure illustrates a sketch he provided to guide plowing practices in farm fields with artificial drainage to help avoid sedimentation problems (modified from Ruffin 1861).

early 1900s. The first annual drainage convention met in New Bern in 1908 (Pratt 1908). One of the key supporters was the state geologist, Joseph Hyde Pratt, who encouraged participation in the drainage movement at the drainage conventions from 1908 till 1916. Congressman John Small of Washington, North Carolina was also a strong supporter of expanding drainage enterprises and he drafted a bill, the North Carolina Drainage Act, that was passed by the North Carolina General Assembly in 1909 (Ross 1973). The 1909 Drainage Act permitted farmers to consolidate their holdings into groups, approved bonds for sale to pay for drainage works, and allowed farmers to repay the loans over time (Ross 1973). The 1909 Drainage Act was described as "an act to promote the public health, convenience and welfare by leveeing, ditching and draining the wet, swamp and overflowed lands of the state" (Pratt 1909). The Act allowed the establishment of drainage districts throughout North Carolina and more extensive drainage projects. The general purpose of the districts was to provide effective drainage outlets for farms and reduce flooding for the district as a whole. After the 1909 Drainage Act, organized drainage expanded rapidly. By 1920, 81 drainage districts were organized. At this time approximately 219,674 hectares (542,828 acres) were drained in North Carolina (Fig. 1) or approximately $1.6 \%$ of the land area (U.S. Bureau of the Census 1922). 


\section{U.S. Drained Agricultural Lands, 1985}

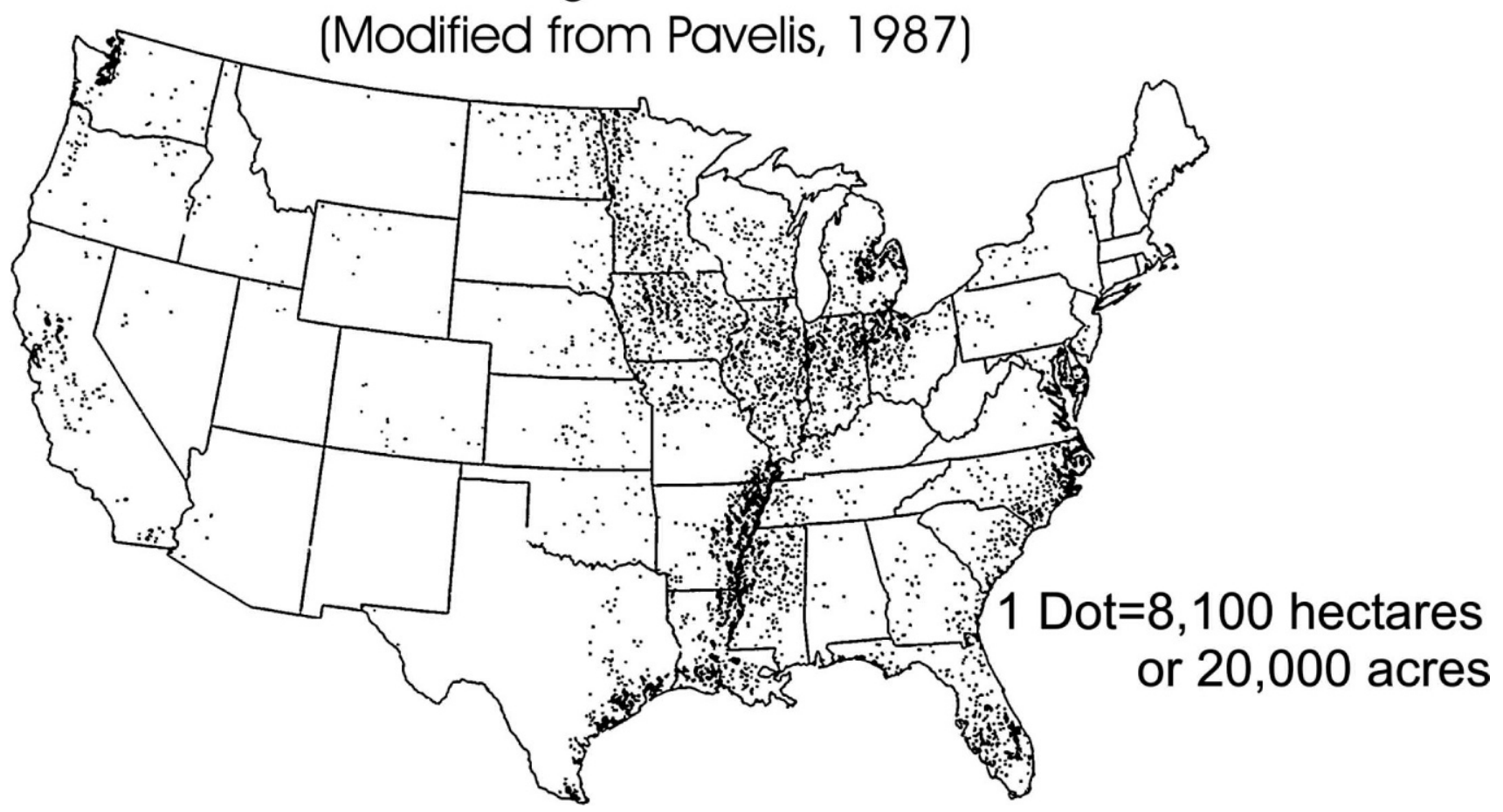

FIG. 3. Most recent estimate of the extent of drained agricultural lands in the U.S. (modified from Pavelis 1987). In 1985, North Carolina was estimated to have 2.2 million hectares (5.4 million acres) of drained agricultural lands, most located in the eastern portion of the state.

As agricultural drainage became more important in the U.S., the 14th U.S. Census in 1920 began to collect data on agricultural drainage enterprises throughout the nation, as well as statewide summaries of drainage (U.S. Bureau of the Census 1922). The census collected data on drainage in 1920, 1930, 1940, 1950, 1959, 1969, and lastly in 1978. U.S. Census maps of agricultural drainage extent were generated from 1920-1960 (Fig. 1). These data document the large expansion of agricultural drained lands in eastern North Carolina from 1920 to 1960.

Additionally, a national synthesis of agricultural drainage was documented by Pavelis (1987) (Fig. 3). This 1985 drainage estimate is the most recent estimate for the United States since the decennial census of drainage was eliminated by Congress in 1986. Pavelis (1987) estimated in 1985 that approximately 44.5 million hectares (110 million acres) of farmland was drained in the U.S. Based on these estimates, North Carolina contained approximately 2.2 million hectares (5.4 million acres) of drained agricultural lands in 1985. Using the Pavelis (1987) and more recent state-wide estimates from 1992 by Jaynes and James (2007), the approximate extent of agricultural drainage in North Carolina ranges from 9-17\% of the land area, approximately an order of magnitude larger than when drainage districts began in the early 1900 s $(1.6 \%$ of land area, 219,674 hectares or 542,828 acres).
Based on U.S. Census data it is difficult to track the changes in extent of agricultural drainage over time after 1974, because of a change in surveying methodology in 1978. However, earlier data from the census (19201974) suggest that the extent of drained lands in North Carolina peaked around the 1960s (Fig. 4) and expansion in the extent of drained lands has subdued since then. This decline in new drainage activities is also evident in the decreasing number of drainage districts in North Carolina over time. In 1920, the U.S. Census noted that 81 drainage districts were located in the state; decreasing to 53 in 1978 (U.S. Bureau of the Census 1980). The most recent estimate of drainage districts by the U.S. Bureau of the Census (2007) documented 41 drainage districts in North Carolina, of these, 40 exist in the Coastal Plain and one in the Blue Ridge Mountains.

The expansion of drainage districts and agricultural drainage in eastern North Carolina during the 1900s contributed to wetland losses. The loss of wetlands in North Carolina from 1780 to 1992 has been estimated at 53\%, with most occurring in eastern North Carolina (USDA 1997). The national data suggest that up until the 1970s agriculture was the main cause of wetland loss but, more recently (since the 1980s) urban development has become the major cause of wetland losses. This shift is in part because of changes in federal agricultural wetland policy (Skaggs et al. 1994). 


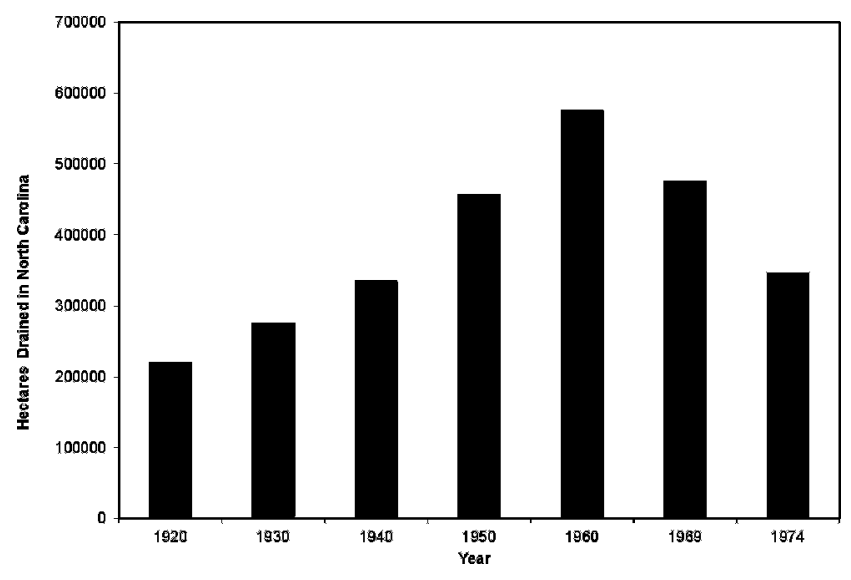

FIG. 4. U.S. Census estimates of drained agricultural lands in North Carolina (1920-1974; U.S. Bureau of the Census 1922, 1932, 1942, 1952, 1961, 1973). Note: estimates after 1974 used a different sampling methodology. During the 1978 census, it was noted that attempts to enumerate acreage of artificially drained agricultural land by individual farm owners tended to underestimate the actual extent of drained lands (Bureau of the Census 1980). In the 1978 Census of Agriculture, instead of individual farm owner surveys, the estimates of drained land were based on a new approach that used records from state and county Soil Conservation Service offices to develop estimates. This change in sampling methodology does not permit direct comparison of the census data before 1978 and after 1978.

A growing awareness of the environmental impacts of agricultural drainage in the 1970 s contributed to the decline in new drainage activity in eastern North Carolina. The filing of a lawsuit in eastern North Carolina played a key role in changing the public perception of agricultural drainage and its effects on streams and wetlands during the 1970s. The Chicod Creek watershed received national attention because of concerns related to the environmental impacts of channelization. As described by Brookes (1988), "The Chicod Creek lawsuit may be the landmark case over channelization in the USA." The Soil Conservation Survey (SCS) planned to excavate $106 \mathrm{~km}$ of stream channel in August 1971, to reduce crop loss because of flooding in the Chicod Creek watershed in Pitt and Beaufort counties of North Carolina. The Natural Resources Defense Council and others pursued a lawsuit to oppose the SCS's plans in November 1971. A compromise was reached in 1977, which required before and after studies to be conducted, and modifications limiting sediment transport and impacts to fish, wildlife, vegetation and habitat. Net results of the lawsuit included more planning, involvement, and input from fish and wildlife organizations, and SCS guidelines that include environmental objectives along with drainage and flood protection (Brookes 1988).

Prior to the 1970s, wetland drainage was generally encouraged in the U.S. Regulations such as Public Laws 534 and 566 helped fund flood control and drainage structures beginning in the 1940s (USDA 1997). After
1977, Executive Order 11,990 revised these programs to limit wetland impacts. After the late 1970s, federal policy has tended to encourage wetland preservation with regulations, such as the Food Security Act of 1985, which included wetland conservation provisions (also referred to as Swampbuster) that denied eligibility for certain funding/loan programs to farmers that planted on recently converted wetlands (USDA 1997) and the Clean Water Act (Federal Water Pollution Control Act) passed in 1972 and amended in 1977, which protected wetlands as part of the drainage network and "waters of the United States" (Leibowitz et al. 2008).

A decline in new agricultural drainage activity in North Carolina, after the 1970s, is in agreement with patterns in other states as noted in the 1978 Census, and by Pavelis (1987). The 1978 Census of Agriculture (U.S. Bureau of the Census 1980) noted a national decline in new drainage activity because of: a decrease in the extent of potentially productive lands requiring drainage; completion of most of the feasible large-scale drainage projects; technological advances that allowed private farmers to install their own systems; changes in federal policy from encouraging drainage to a present policy of discouraging drainage of wetlands and encouraging wetland conservation. New agricultural drainage projects after the 1970s tended to focus on maintenance and renovation of existing systems (U.S. Bureau of the Census 1980).

\section{AGRICULTURAL DRAINAGE AND ITS BENEFITS}

Agricultural drainage is typically accomplished by surface and/or subsurface drainage. Surface drainage (also referred to as conventional agricultural drainage) includes ditching and channelization. Surface drainage increases the hydraulic capacity of the channelized streams or ditches and reduces flooding of the adjacent farmland (Evans et al. 2007). Surface drainage systems in the Coastal Plain of North Carolina commonly consist of open field ditches that are spaced approximately $100 \mathrm{~m}$ apart and the land surface is sloped toward the ditches to facilitate surface drainage to the ditches (Gilliam and Skaggs 1986) (Fig. 5A). These systems generally drain surface water runoff but can also help lower the water table. However, subsurface drainage is more effective at lowering the water table than conventional (surface) drainage. Subsurface drainage is commonly accomplished with buried, perforated PVC or clay pipes and is often referred to as tile drainage (Fig. 5B). The general result is a lowering of the water table and a reduction in the proportion of outflow discharge that is composed of surface runoff (Gilliam and Skaggs 1986). More recently, controlled drainage has been implemented to reduce nutrient exports from drained agricultural lands (Fig. 5C) (Evans et al. 1992, Evans et al. 1995). 

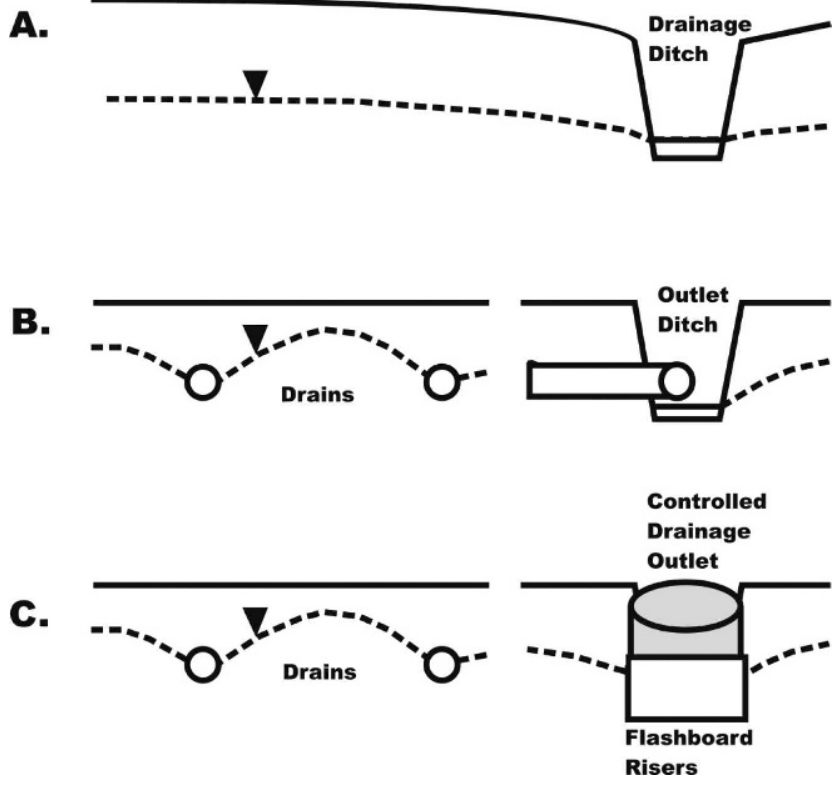

FIG. 5. Common forms of agricultural drainage practiced in eastern North Carolina. (A) surface drainage; (B) subsurface drainage; and $(\mathrm{C})$ controlled drainage.

These drainage alterations can produce numerous benefits for the landowner. The primary benefits include improvements in crop growth and land productivity, improved access for farm machinery and reduction in flooding, all of which in turn can result in increased income (Fausey et al. 1987). The lowering of the water table in drained agricultural lands can also improve opportunities for on-site wastewater treatment, which may have been impossible because of shallow water tables present before agricultural drainage was implemented. Reduction in surface runoff, as the result of subsurface drainage, can reduce erosion and sediment transport to adjacent surface water bodies. Public and environmental health benefits have also been documented as drainage of agricultural lands has been shown to reduce diseases of crops and livestock and decrease the extent of mosquito habitat, which can decrease the spread of disease to humans (Fausey et al. 1987). Agricultural drainage can also increase real estate values. For example, Pavelis (1987) compared farm land real estate value in 23 highly drained agricultural counties in the southeastern U.S. (South Carolina, Georgia, and Florida) with 252 other agricultural counties. The highly drained counties had higher real estate values per acre than the counties that were not highly drained.

\section{HYDROLOGICAL AND WATER QUALITY EFFECTS OF AGRICULTURAL DRAINAGE}

\section{Hydrological Effects of Agricultural Drainage}

The majority of agricultural drainage in North Carolina has been focused in the eastern portion of

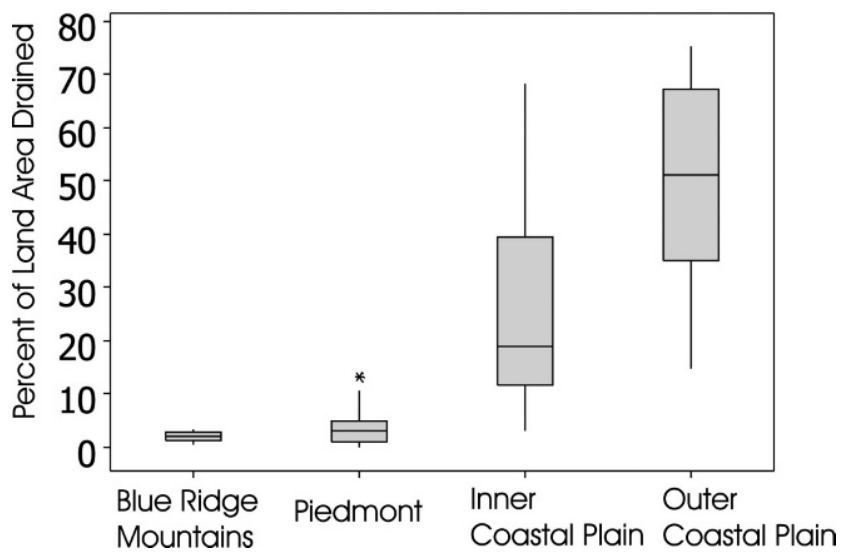

FIG. 6. Box-plots of the percentage of county land drained for agriculture in the four main physiographic regions of North Carolina (data source: U.S. Bureau of the Census 1980).

the state, because of the gentle slope, shallow water tables, and extensive wetlands common in the Coastal Plain. The Coastal Plain (Inner and Outer) comprises approximately $44 \%$ of the state, but contains $89 \%$ of the drained lands in North Carolina (Figs. 1, 6). Based on the most recent county-wide data estimates from the Census of Agriculture (U.S. Bureau of the Census 1980), the median percentage of land drained in the North Carolina Coastal Plain is $36 \%$, and the maximum percentage of drainage is $75 \%$ for Washington County. Overall, the Outer Coastal Plain (51\% of land drained; median countywide estimate) has more extensive drainage than the Inner Coastal Plain (19\% of land drained; median countywide estimate). Agricultural drainage is more extensive in the Outer Coastal Plain because it is closer to sea level, has a gentler slope, shallower water tables, and less permeable soils than the Inner Coastal Plain (Winner and Coble 1996).

A wide range of studies have documented changes to hydrology associated with agricultural drainage in eastern North Carolina. In one of the earliest studies, Heath (1975) observed discharge data from Ahoskie Creek before (1951-1962) and after (1964-1972) channelization in Hertford County. Channelization resulted in an increase in groundwater baseflow. The maximum discharges (exceeded 5\% of the time) were larger after channelization. Evans et al. (1995) summarized annual discharge at 14 North Carolina sites and found a slight increase in total outflow discharge $(5 \%)$ for surface agricultural drainage and moderate increase $(20 \%)$ in total outflow for subsurface agricultural drainage relative to undrained forested sites. Subsurface drainage systems had less of an impact on storm peaks than surface drained systems (Evans et al. 1995). Surface and subsurface agricultural drainage increased peak flows by approximately 2 to 4 times compared to natural forested sites, but varied depending on storm intensity, soil 
moisture, drainage intensity and type. During storm events peak outflow rates were approximately two times larger for surface drained agricultural sites, when compared to subsurface drained agricultural sites (Evans et al. 1995). Gilliam and Skaggs (1986) in a paired watershed study, found little difference in total annual discharge from agricultural (drained) and undeveloped lands in the Outer Coastal Plain, but peak runoff rates during storm events were approximately three times greater and occurred earlier on agricultural lands in contrast to undeveloped lands. They also compared hydrological response to rainfall at an adjacent 32 ha agricultural watershed in Belhaven, North Carolina to evaluate the effects of subsurface drainage on hydrological response. Subsurface drainage generally reduced peak runoff, by approximately $50 \%$ relative to the (conventional) surface drainage. Simulation modeling revealed that annual surface runoff could be reduced by more than a factor of three by installing drains with closer spacing $(15-100 \mathrm{~m})$ (Gilliam and Skaggs 1986). This work indicated that agricultural drainage system design can have a large influence on surface runoff response.

Results from Evans et al. (1995) and Gilliam and Skaggs (1986) are in agreement with estimates by Stone et al. (1995) for the eastern Coastal Plain of the U.S. Stone et al. (1995) showed that agricultural drainage can increase runoff peaks downgradient by $3-4$ times in contrast to undeveloped lands. Similarly, in a later literature review, Skaggs et al. (1994) summarized that in most cases, conversion from natural drainage to improved drainage for agriculture has resulted in increased peak runoff rates. Using a modeling approach, Konyha et al. (1992) evaluated hydrological responses to a variety of agricultural drainage methods including: conventional drainage (open field ditches); improved subsurface drainage (subsurface drain pipes); controlled drainage during the growing season (weirs and artificial structures); and semi-continuous controlled drainage (weirs and artificial structures). Although subsurface and controlled drainage were shown to reduce storm runoff, the response decreased with catchment size. Overall, these studies revealed that soils, climate, management technique and watershed-size can help explain the variability in hydrological response to agricultural drainage in eastern North Carolina.

Stream channel morphology is also altered by agricultural drainage. O’Driscoll et al. (2009) found that agricultural channelization enlarged the dimensions of approximately $20 \%$ of the rural streams studied in the Inner Coastal Plain. Urbanization within these formerly agricultural watersheds results in further enlargement of channels in response to increased stormwater runoff (O’Driscoll et al. 2009). Bankfull discharge events for natural Coastal Plain streams have been documented to occur several times a year (Sweet and Geratz 2003), however typical drainage improvements for agricultural streams enlarge the channel to convey the 2 to $5 \mathrm{yr}$ storm flows (Evans et al. 2007). Agricultural channel dimensions are approximately an order of magnitude larger than their natural counterparts (Evans et al. 2007). A disconnect between streams and their natural floodplains can occur along incised channels (Evans et al. 2007; Hardison et al. 2009), resulting in a decline in water quality and sediment trapping functions along the channelized streams. Mason et al. (1990) documented channelization effects on Chicod Creek channel morphology. Prior to channelization, bankfull discharge occurred frequently (approximately 20\% of the time) and stream channels were shallow, braided, and poorly defined. After channelization, the channel was welldefined with steep banks and bankfull discharge only occurred approximately $2 \%$ of the time (based on flowduration curves). The removal of channel debris resulted in smoother channels with less frictional resistance, resulting in greater streamflow velocities and more rapid storm peaks (Mason et al. 1990). Channelization can lead to channel evolution upstream of the disturbance, as knickpoints at slope changes proceed upstream, channel incision can migrate to the headwaters and reduce channel stability while increasing downstream sediment transport and further disconnecting the stream and floodplain (Simon 1989).

Agricultural stream channelization can also increase stream length and drainage density. In one of the earliest studies on agricultural drainage in eastern North Carolina, Heath (1975) observed that agricultural drainage increased stream drainage density by approximately an order of magnitude in the Outer Coastal Plain. These drainage practices alter wetland extent and functionality. Cashin et al. (1992) in their study of wetland alterations in the North Carolina Coastal Plain from the 1950s to the $1980 \mathrm{~s}$, found that agricultural land-use conversion was responsible for over $40 \%$ of the total wetland alteration over that period. Alterations were generally related to drainage associated with forestry $(53 \%)$, agricultural $(42 \%)$, urban $(2 \%)$ and military land-use conversion.

Agricultural drainage has also been shown to indirectly affect wetland function. Changes in groundwater levels associated with agricultural drainage can affect the hydrology of riparian wetlands. Effects of channelization on groundwater levels and crop yields were investigated in Mitchell Creek watershed (Pitt and Edgecombe counties) (Doty et al. 1982). The 2-4 m deep channel provided effective drainage and flood control functions during runoff events, but it was shown that overdrainage of the sandy, near-stream aquifer resulted in a decline in crop yields. Groundwater level measurements adjacent to the channelized stream revealed that 
over-deepened agricultural channels ( $3 \mathrm{~m}$ deep) could result in water table drawdown as far as $834 \mathrm{~m}$ perpendicular to the creek. Mason et al. (1990) conducted a detailed before and after channelization study of the Chicod Creek drainage basin (Pitt and Beaufort Counties, North Carolina) during the period of 1975-1987. In 1975, prior to drainage modifications, they measured baseline groundwater level conditions. They observed groundwater level declines of up to $0.12 \mathrm{~m}$ at a distance of $55 \mathrm{~m}$ from the channel after channelization. In a more recent study in the Greenville, North Carolina region, Hardison et al. (2009) showed that stream channel incision along low-order Coastal Plain streams could result in riparian water table declines of up to $2 \mathrm{~m}$.

Overall, the conversion of wetlands and forested lands to drained agricultural lands in eastern North Carolina has impacted stream hydrology, geomorphology and the adjacent riparian zones (Table 1). Responses include: increased peakflows; increased baseflow; increased drainage density; increased channel conveyance; decreased stream-floodplain connection; decreased stream channel geomorphologic heterogeneity; reduced wetland extent; and declines in groundwater levels within several hundred meters of the channel.

\section{Water Quality Effects of Agricultural Drainage}

Watershed-scale studies in eastern North Carolina have shown that agricultural land-use has led to elevated nutrient concentrations in groundwater, streams, and estuaries (McMahon and Harned 1998; Spruill et al. 1998; Cooper et al. 2004). However, these studies did not directly isolate the effects of surface or subsurface agricultural drainage on water quality. At the field-scale, agricultural drainage can affect water quality because ditches and drainpipes can act as conduits that may transport agricultural fertilizers, manure, and pesticides to surface waters. In one of the earliest studies of agricultural channelization effects on stream water quality, Kuenzler et al. (1977) targeted seven streams in Edgecombe, Pitt, and Craven Counties. They compared water quality data from three natural streams with water quality data from four channelized streams. Agricultural land-use included croplands, hog, and poultry farms. Results indicated that channelization increased stream water conductivity, dissolved oxygen, turbidity, $\mathrm{pH}$, nitrate-nitrogen, and phosphorus concentrations. Using a similar paired watershed approach, Gilliam and Skaggs (1986) evaluated the effects of agricultural drainage on water quality in the Outer Coastal Plain. They compared nitrogen and phosphorus exports from surface-drained crop fields (corn-soybean rotation) and forested fields over a three-year period and found that nitrogen exports were $15.2-16 \mathrm{~kg} / \mathrm{ha} / \mathrm{yr}$ for the crop fields, in contrast to
3.6-5.7 kg/ha/yr for the forested sites. They found phosphorus losses were low from mineral soils (both cropped and forested fields) and for a forested field with organic soils, however from crop fields with organic soils the P losses were elevated $(7.6 \mathrm{~kg} / \mathrm{ha})$. Evans et al. (1995) compared phosphorus export for natural, surface-drained, and subsurface-drained mineral soil sites (draining unspecified row crops) in eastern North Carolina. Phosphorus transport was greatest for surface drainage. Subsurface drainage reduced phosphorus transport by approximately 50\% in contrast to surface drainage.

Modeling approaches have also been used to evaluate the effects of agricultural drainage on water quality because of the complex drainage processes and interactions between soils, vegetation, hydrology, drainage technique, and climate. Deal et al. (1986) estimated the nitrogen and phosphorous exports related to a variety of agricultural (row crops) management scenarios across a range of soil textures (sandy loam to clay) in a DRAINMOD modeling study of six North Carolina soil series. They found that sites with good subsurface drainage could increase nitrogen export by $17-35 \mathrm{~kg} / \mathrm{ha} /$ yr relative to systems with poor subsurface drainage; these exports were slightly higher than those found by Gilliam and Skaggs (1986) $(<16 \mathrm{~kg} / \mathrm{ha} / \mathrm{yr})$. Model results also showed a slight decrease in phosphorus export when subsurface drainage was good in contrast to systems with poor subsurface drainage. Another component of their research was to evaluate the effects of controlled drainage (using mechanical controls to slow or prevent drainage from leaving the field area during portions of the growing season). Their models estimated that nitrate losses could be decreased by up to $34 \%$ with controlled drainage, but losses were variable across soil types and drainage management techniques (Deal et al. 1986).

Skaggs et al. (1994) included numerous studies from eastern North Carolina in their review of agricultural drainage effects on water quality in the U.S. and Canada. They documented an increase in nutrient and sediment loads to streams at sites with agricultural drainage, however they found a high degree of spatial and temporal variability in solute transport from drained agricultural lands. Their review showed that conventional (surface) drainage may reduce nitratenitrogen losses relative to subsurface drainage, but phosphorus losses may be increased. Subsurface drainage can reduce sediment and phosphorus losses but has been shown to increase nitrate-nitrogen losses (Skaggs et al. 1994).

Land-use conversion (from forested land to drained agricultural land) can lead to increased erosion and sediment transport. In a detailed before and after channelization study at Chicod Creek, North Carolina, 
Table 1. Documented effects of agricultural drainage on stream hydrology and water quality in eastern North Carolina.

\begin{tabular}{|c|c|c|}
\hline Location & Effects & Reference \\
\hline Hertford Co. & $\begin{array}{l}\text { Increase in groundwater baseflow and stream drainage density by } \\
\text { approximately an order of magnitude. }\end{array}$ & Heath (1975) \\
\hline $\begin{array}{l}\text { Edgecombe, Pitt, } \\
\text { Craven Co. }\end{array}$ & $\begin{array}{l}\text { For (3) natural vs. (4) channelized streams, channelization increased } \\
\text { stream conductivity, d.o., turbidity, } \mathrm{pH} \text {, nitrate and phosphorus. }\end{array}$ & Kuenzler et al. (1977) \\
\hline Pitt, Edgecombe Co. & $\begin{array}{l}\text { Groundwater levels adjacent to Mitchell Creek revealed that channelization } \\
\text { ( } 3 \mathrm{~m} \text { deep) could result in drawdown } 834 \mathrm{~m} \text { from creek. }\end{array}$ & Doty et al. (1982) \\
\hline Coastal Plain & $\begin{array}{l}\text { Drainage models for Goldsboro sandy loam soils, estimated that subsurface } \\
\text { drainage could reduce erosion by an order of magnitude }\end{array}$ & Skaggs et al. (1982) \\
\hline Outer Coastal Plain & $\begin{array}{l}\text { Storm peak flows were approximately } 3 \text { times }>\text { on drained ag. lands } \\
\text { vs. undeveloped lands. Subsurface drainage reduced peak flows. }\end{array}$ & Gilliam and Skaggs (1986) \\
\hline Outer Coastal Plain & $\begin{array}{l}\mathrm{N} \text { exports were } 15-16 \mathrm{~kg} / \mathrm{ha} / \mathrm{yr} \text { for surface-drained croplands, } 3.6-5.7 \\
\mathrm{~kg} / \mathrm{ha} / \mathrm{yr} \text { for the forested sites. Elevated } \mathrm{P} \text { losses from crop fields. }\end{array}$ & Gilliam and Skaggs (1986) \\
\hline Outer Coastal Plain & $\begin{array}{l}\text { Sites with good subsurface drainage had greater } \mathrm{N} \text { export }(17-35 \mathrm{~kg} / \mathrm{ha} / \mathrm{yr}) \\
\text { vs. poor subsurface drainage. Controlled drainage decreased } \mathrm{N} \text {. }\end{array}$ & Deal et al. (1986) \\
\hline Pitt Co. & $\begin{array}{l}\text { Prior to channelization of Chicod Creek, bankfull discharge occurred } \\
\text { approximately } 20 \% \text { of the time. After channelization } 2 \% \text { of the time. }\end{array}$ & Mason et al. (1990) \\
\hline Pitt Co. & $\begin{array}{l}\text { In Chicod Creek watershed, sediment discharge increased during } \\
\text { channelization, returned to pre-disturbance levels after modification. }\end{array}$ & Mason et al. (1990) \\
\hline Beaufort, Tyrell Co. & $\begin{array}{l}\text { Subsurface drainage reduced storm peaks by } 72 \% \text { relative to surface } \\
\text { drainage for a field but decreased only } 35 \% \text { for a larger watershed. }\end{array}$ & Konyha et al. (1992) \\
\hline Coastal Plain & $\begin{array}{l}\text { Agricultural land-use conversion caused over } 40 \% \text { of the total wetland } \\
\text { alteration in the NC Coastal Plain from the 1950s to the 1980s. }\end{array}$ & Cashin et al. (1992) \\
\hline 14 North Carolina sites & $\begin{array}{l}\text { Ag. drainage increased storm peak flows by } 2 \text { to } 4 \text { times compared } \\
\text { to natural sites. Greater peaks for surface vs. subsurface drainage. }\end{array}$ & Evans et al. (1995) \\
\hline Coastal Plain & $\begin{array}{l}\text { Aldicarb (pesticide) from ag. plots dissipated after } 61 \text { days, was primarily } \\
\text { found at depths }<0.15 \mathrm{~m} \text {. Rainfall led to elevated mobility. }\end{array}$ & Munster et al. (1995) \\
\hline Pitt, Greene Co. & $\begin{array}{l}\text { Fields received fertilizer, swine effluent, wastewater sludge. Highest nitrate } \\
\text { concentrations were at tile sites receiving swine effluent. }\end{array}$ & Harden and Spruill (2004) \\
\hline Pitt Co. & $\begin{array}{l}\text { At Swift Creek, crop harvesting and ditch mowing in fall resulted in } \\
\text { increased sed. transport. Ditches reduced downstream inputs. }\end{array}$ & Lecce et al. (2006) \\
\hline Goldsboro & $\begin{array}{l}\text { Nutrient transport from croplands, a swine farm, and dairy cow } \\
\text { pastures was compared. Highest } \mathrm{N} \text { concentrations from swine farm. }\end{array}$ & Dukes and Evans (2006) \\
\hline $\begin{array}{l}\text { Pitt, Edgecombe, Greene, } \\
\text { Lenoir Co. }\end{array}$ & $\begin{array}{l}\text { Agricultural channelization enlarged the dimensions of approximately } 20 \% \\
\text { of the rural streams studied in the Inner Coastal Plain. }\end{array}$ & O'Driscoll et al. (2009) \\
\hline
\end{tabular}

Mason et al. (1990) found that although a variety of water quality parameters were monitored (dissolved oxygen, temperature, suspended sediment, $\mathrm{pH}$ ), only suspended sediment showed significant increases after channelization (agriculture in the watershed included tobacco, soybeans, and corn, poultry and swine farms). At the Juniper Branch tributary, sediment discharge increased from 20 tons/day to 50 tons/day for 100 cubic feet per second (cfs) flows during modification, but returned to near pre-disturbance levels after modification. Lecce et al. (2006) conducted a sediment budget to evaluate the effects of agricultural drainage on sediment transport and storage in a study of sediment transport in the headwaters of the Swift Creek watershed, Pitt County. Seasonally, crop harvesting and ditch mowing in late fall resulted in conditions more favorable to erosion and sediment transport. As crops and ditch vegetation grew in spring, sediment transport decreased. Headwater ditches had the capacity to store large amounts of sediment on site, reducing the influence of erosion and sediment transport on downstream waterways (Lecce et al. 2006). Generally, soil erosion increases with surface runoff, therefore subsurface drainage can reduce sediment transport from farm fields. Skaggs et al. (1982) estimated that subsurface drainage could reduce annual erosion by approximately an order of magnitude, because of the decrease in surface runoff in a modeling study of Goldsboro sandy loam soils in eastern North Carolina.

Recent work by Harden and Spruill (2004) evaluated the effects of fertilizer type on agricultural drainage waters emanating from seven surface ditches and eleven tile drains in the Middle Swamp Watershed, eastern North Carolina. They sampled approximately monthly, for a year, in fields receiving commercial fertilizer, swine lagoon effluent, and wastewater-treatment plant sludge. The highest median nitrate-nitrogen concentrations were measured for tile-drained sites receiving swine lagoon effluent (32 mg/l) (Harden and Spruill 2004). Surface-drained sites receiving swine lagoon effluent also had higher nitrate-nitrogen concentrations $(8.2 \mathrm{mg} /$ 1) than other surface drained sites (Harden and Spruill, 2004). Instantaneous estimates of nitrate loading were significantly higher at the tile-drained swine lagoon 
effluent sites than all other sites; median annual nitrate loading was estimated to be approximately $150 \mathrm{~kg} / \mathrm{ha} / \mathrm{yr}$. In contrast, tile drain sites receiving commercial fertilizer exported approximately $9 \mathrm{~kg} / \mathrm{ha} / \mathrm{yr}$ of nitrate. Temporal variations in nitrate yield were primarily influenced by differences in discharge over time, and temporal variations in concentration were likely related to timing and magnitude of fertilizer application.

Harden and Spruill's work (2004) was in general agreement with earlier studies by Gilliam and Skaggs (1986) and Deal et al. (1986) that revealed that tile drainage (subsurface drainage) can increase the export of nitrate from agricultural lands. Dukes and Evans (2006) recently compared nutrient transport from agricultural drainage of croplands, a swine farm, and dairy cow pastures in the Coastal Plain, near Goldsboro, North Carolina. They found the highest concentrations of inorganic nitrogen to be associated with the swine farm and $\mathrm{NH}_{4}-\mathrm{N}$ concentrations in groundwater averaged $121 \mathrm{mg} / \mathrm{l}$, presumably because of leakage from the unlined swine waste lagoon. These studies and others (e.g., Mallin and Cahoon 2003) suggested that swine farms in eastern North Carolina may be hotspots for nutrient export, exacerbated by drainage modifications.

Several decades of focused research (e.g., Skaggs et al. 1994, Birgand et al. 2007) have greatly improved the understanding of nutrient transport from drained agricultural lands. Much less work has been done on the effects of agricultural drainage on pesticide and herbicide transport in this region. Munster et al. (1995) conducted a study that focused on Aldicarb (pesticide) transport via agricultural drainage in North Carolina. They compared Aldicarb transport from conventional drainage, controlled drainage, and subirrigation plots. Aldicarb dissipated after 61 days and was primarily found in samples with depths shallower than $0.15 \mathrm{~m}$. Although Aldicarb concentrations were similar for surface runoff at the three plots, the water table depth was shallowest at the subirrigation plot, which resulted in greater surface runoff and more transport of Aldicarb off the plot $(0.06 \%$ of Aldicarb applied was lost as surface runoff). Aldicarb concentrations in shallow groundwater $(0.61 \mathrm{~m}$ deep) reached concentrations as high as $42 \mathrm{ppb}$, which were 14 times greater than the EPA health advisory concentrations for drinking water at the time of the study (1995). (Note: in 2010 EPA introduced a regulatory action to end Aldicarb use because of public health concerns (EPA 2010).) Rainfall events caused the water table to rise and led to elevated concentrations of Aldicarb, suggesting the importance of runoff events to Aldicarb transport. These results are in agreement with Kladivko et al. (2001), who summarized over 30 studies on pesticide transport to tile drains in North America. Kladivko et al. (2001) found that pesticide concentrations were generally higher in surface runoff in contrast to subsurface drainage. However, pesticide concentrations in tile drain waters can be elevated when preferential flow during rainfall events occurs shortly after pesticide applications (Kladivko et al. 2001). At the watershed-scale, several USGS studies in eastern North Carolina have revealed elevated herbicide and pesticide concentrations in surface waters draining from agricultural lands (Harned et al. 1995; Woodside and Ruhl 2001). Evans et al. (1995) and these studies have indicated a better understanding of pesticide transport via agricultural drainage is needed in eastern North Carolina.

Overall, the conversion of wetlands and forested lands to drained agricultural lands in eastern North Carolina has impacted stream water quality by increasing nutrient, sediment, and pesticide inputs to streams, relative to background conditions (Table 1).

\section{STRATEGIES TO IMPROVE AGRICULTURAL DRAINAGE WATER QUALITY}

Several major strategies have been used to address nutrient, sediment, and pesticide transport from drained agricultural lands to downstream receiving waters. These include: 1) agronomic management practices; 2) controlled drainage; 3) riparian buffers; and 4) channel alterations. Agronomic management practices such as nutrient management, irrigation management, tillage, and crop rotations, can all play a role in drainage water quality management. Recently, work by Skaggs et al. (2006) has shown that nitrate exports from drained farm fields increase as the drainage intensity increases. Skaggs et al. (2006) used a modeling approach to estimate the optimum drainage design for maximum corn production. Modeling approaches that consider both crop production and nitrate losses can be useful tools to decrease water quality impairments while promoting crop production. One of the steps towards improving water quality is educating farmers on the link between their current agronomic techniques and water quality, and the available agronomic management practices to improve water quality (Strock et al. 2010). However, even when the link is established, minimizing the transfer of agricultural pollutants to surface and ground waters requires persistent efforts by the farmer that generally are more costly to the farmer than conventional approaches (Strock et al. 2010). Cost-sharing programs can provide greater incentives to farmers to improve water quality on-site (Brinson and Eckles 2011).

Controlled drainage has been implemented in eastern North Carolina to improve the water quality of agricultural drainage. The controlled drainage approach utilizes a structure, such as a flashboard riser (Fig. 5C) 
to hold water back and manage drainage at the outlet. In eastern North Carolina, Evans et al. (1995) documented that controlled drainage can reduce outflows by up to $30 \%$, depending on the duration over which water is held back. The authors estimated that if fully implemented, the reduction of nitrogen inputs to surface waters could be as large as 100 million $\mathrm{kg} / \mathrm{yr}$. To maximize the potential water quality benefits, more work is needed to understand the influence of controlled drainage on the temporal and spatial variations in agricultural drainage quality (Evans et al. 1995). Dukes et al. (2003) compared water quality of agricultural drainage along stream reaches with controlled drainage, controlled drainage and riparian buffers, and just riparian buffers. They showed that nitrate concentrations in groundwater were reduced by $29 \%$ adjacent to the riparian buffer, but nitrate reductions of $63-73 \%$ were measured for the controlled drainage sections. They concluded that more information is needed on the spatial variability of sediment hydraulic conductivity and the effects on controlled drainage effectiveness.

Streams and riparian buffers can ameliorate some of the effects of excess nutrient exports through a variety of in-channel and riparian uptake, sorption, transformation and retention processes. In their review of nitrogen removal in streams of agricultural catchments, Birgand et al. (2007) documented that in-stream and riparian processes can result in nitrogen transformation or retention of $10-70 \%$ of the nitrogen load. Using sediment cores from the Open Grounds farm site in eastern North Carolina, McMillan et al. (2010) showed that algal biomass in agricultural headwater streams could stimulate denitrification. Also, at the Open Grounds farm site, Ensign et al. (2006), quantified instream nutrient uptake along first-order drainage ditches and found 65-98\% of the $\mathrm{NH}_{4}{ }^{+}$and $\mathrm{PO}_{4}{ }^{3-}$ flux was attenuated by in-stream processes. Similarly, riparian buffers have been shown to improve the quality of groundwater discharging to streams from agricultural lands in eastern North Carolina (Spruill 2004). However, when agricultural drainage practices, such as channelization, result in deeper riparian water tables, the denitrification processes that typically occur in shallow-organic rich floodplain areas may be shortcircuited (Puckett 2004).

Evans et al. (2007) documented that a variety of channel management strategies can be implemented to improve agricultural drainage quality in their study of seven projects in eastern North Carolina. These approaches included: in-stream and riparian wetlands; lowering of the floodplain; redesign of channels (Powell et al. 2007a, b); and conservation easements for riparian buffers. Although these approaches resulted in water quality improvements and/or downstream flow improvements, costs varied dramatically. The lowest costs were associated with wetland planting in an existing channel, and the greatest costs linked to artificial floodplain construction. Recently, other approaches have been developed to treat drainage waters onsite. Denitrification drainage bioreactors have been designed to ameliorate water quality problems associated with nitrate export from drained agricultural lands (Christianson et al. 2011). Three plywood bioreactors filled with woodchips were constructed to receive agricultural discharge water in a pilot study near Ames, Iowa. The study revealed that, with retention times of four to eight hours, the nitrate loads in agricultural drainage could be reduced by $30-70 \%$. With longer residence times $(>8 \mathrm{hr}$ ) nitrate loads could be reduced by up to $100 \%$ (Christianson et al. 2011). Penn et al. (2007) have recently pioneered an approach to use phosphorus sorbing materials (i.e., alum, lime) to sequester dissolved phosphorus from agricultural drainage ditch water. They tested a flow through system using acid mine drainage residual substrate. They found that approximately $99 \%$ of dissolved phosphorus was removed from drainage water that flowed through the system. However, during extreme flow events the efficiency of the system declined as drainage exceeded the design flow. The preliminary results suggest that with proper design, these systems can lead to reductions in phosphorus loading to downstream receiving waters (Penn et al. 2007).

Agricultural drainage ditches require periodic maintenance to maintain their abilities to convey flows. The management of agricultural ditches can also affect surface water quality and discharge regime. For example, ditch cleaning and dredging can disrupt sediment trapping and affect the channel's ability to retain nutrients (Smith and Pappas 2007). Innovative ditch management techniques are being developed to improve water quality and sediment trapping functions. For example, the Maryland Department of Agriculture developed a selective herbicide application approach that controls woody vegetation (to prevent blockages) but allows non-woody vegetation to be maintained to retain sediment, stabilize the channel and provide habitat (Needelman et al. 2007).

\section{FUTURE CHALLENGES}

During the $20^{\text {th }}$ century, the agricultural drainage characteristics of eastern North Carolina have changed dramatically. These farmlands contribute greatly to the state economy. For example, the sales of agricultural products generated more than ten billion dollars in 2007 (U.S. Bureau of the Census, 2007). As future demand for food and fiber increases with growing human populations, drained agricultural lands will continue to play a vital role in the regional economy. Improvements 
in drainage water management can help balance the goals of agricultural production with environmental conservation (Strock et al. 2010). One of the major impacts of agricultural drainage has been the loss of wetland habitat (Richardson 2003). As technological advances in agronomic practices have occurred, crop yields in the U.S. have been increasing since the 1940s (Warren 1998). It is therefore possible that crop yields could be maintained on a smaller footprint and some farmlands could be restored to wetlands (Blann et al. 2009). However, additional incentives would be needed to create new wetland resources (Blann et al. 2009; Brinson and Eckles 2011). Recent estimates of the economic costs of water quality impairment lend support to cost-share programs. For example, work by Dodds et al. (2009) estimated that nutrient-related eutrophication costs approximately $\$ 2.2$ billion a year in the U.S. because of property value losses, impairments to recreational use, habitat, and drinking water.

A recent review of U.S. Department of Agriculture conservation programs documents a number of practices (with financial incentives involved) aimed at conserving and improving wetland ecosystem services, including wetland establishment, wetland management, and riparian buffer establishment and management (Brinson and Eckles 2011). However, wetland restorations may be limited in regions with hydrologically altered landscapes, such as extensively drained farmlands. Recent work by Ardon et al. (2010) in the North Carolina Coastal Plain showed that formerly drained agricultural lands restored to wetlands could retain or transform up to $97 \%$ of the nitrate delivered from inflows and precipitation. However, many farm-scale water quality projects would need to be performed to have a cumulative impact for large watersheds. Therefore, integrated watershed-scale management of agricultural drainage impacts is necessary to maximize the impacts of farm-scale improvements on drainage basin water quality. Wossink and Osmond (2002) showed that in the Neuse watershed, best management practices had a wide range of cost-effectiveness related to nutrient reductions, in part based on physiographic setting. They recommended targeting cost-share programs based on those that are most cost-effective for a particular region. At the broader scale, North Carolina has been using TMDLs (Total Maximum Daily Loads), cost share programs, riparian buffers, and other approaches to better manage nutrient export in many of the Coastal Plain River systems, including the Tar-Pamlico, Neuse, and Cape Fear watersheds (NCDENR 2011).

The U.S. Census records provide some background on the historical extent of agricultural drainage in North Carolina. However, the drainage infrastructure in eastern North Carolina has not yet been digitally mapped. Historical, hard-copy maps and documents on drainage districts are not centrally-located. There is no central authority that has monitored or administered the drainage of all of eastern North Carolina. A centralized database of drainage district records and tile drainage maps would be helpful for assessing regional water quality issues. Some efforts have been made to begin the effort of digitizing drainage district information in Pitt County with the Southeast Drainage Commission (OPIS 2011). The last organized effort to track the extent of agricultural drainage at the county level was in 1978 (U.S. Bureau of the Census 1980). With current geographical information systems and satellite technologies, up-to-date mapping of the nature and extent of the drainage enterprises in eastern North Carolina is possible. Jaynes and James (2007) recently attempted to create current estimates of agricultural drainage extent at the national and state level; future work could build on their efforts. Because row crops and swine farms tend to have the most elevated levels of nutrient transport, maps where these sites coincide with artificial drainage would be helpful in evaluating water quality problems at the watershed-scale. Tile drains can continue to act as fast pathways for contaminant transport to streams even after agricultural lands have been converted for other uses such as housing developments. As former drained farmlands are converted to housing developments, few publically available records exist to document where tile drains were located or where maintenance rights of ways along ditches exist.

Since the 1980s, many advances have been made to reduce the water quality impacts of agricultural drainage in the region, including a wide range of best management practices (BMPs) at the field-scale, such as: controlled drainage; fertilizer management; conservation tillage; and riparian and wetland buffers (Skaggs et al. 1994). One challenge is implementing controlled drainage at the watershed-scale, in some cases where land slopes are steep this may be ineffective. Additionally, recent work has shown that atmospheric deposition of nitrogen plays an important role in watershed nutrient export in eastern North Carolina (Whitall et al. 2003). Although riparian buffers and other BMPs can reduce groundwater nutrient contributions to streams, these approaches will likely have little effect on direct atmospheric inputs of nitrogen to surface waters.

Meteorological events, such as storms and droughts, have a large influence on water quality impacts of agricultural drainage. Although agricultural watershed management may help reduce nutrient export, Stow et al. (2001) and Paerl et al. (2006) suggest that discharge and climate (especially storm magnitude and frequency) play an important role. Nutrient loads are subject to significant temporal variability related to meteorological controls on discharge. In a region that is naturally floodprone and susceptible to tropical storms, a balance exists 
between holding water back to reduce nutrient loading and releasing water to free up storage space to reduce flood risk. Forecasting future impacts of agricultural drainage will require some consideration of potential climate change effects. For example, wetlands that have been drained to facilitate agriculture in the outer Coastal Plain may face saltwater intrusion, inundation, and increased erosion as global climate change causes sea-level increases (Henman and Poulter 2008).

The long-term impacts of agricultural drainage on shallow groundwater and surface water quality in eastern North Carolina are difficult to assess without a long-term shallow aquifer and stream water quality monitoring program. Long-term atmospheric deposition data exists in the region as part of the National Atmospheric Deposition Program (NADP), and in the past, surface water monitoring has been conducted regularly by the North Carolina Department of Environment and Natural Resources (NCDENR) and USGS along many of the larger rivers, such as the Tar and Neuse. The lack of a long-term shallow groundwater and low-order stream water quality monitoring network has prevented further advances in understanding the effects of agricultural drainage in the region. This type of network is important to provide a scientific basis for sustainable water resources management in the region, as land-use and climate change will result in changes in hydrological fluxes and water quality over time. Overall, an improved understanding of the environmental effects of agricultural drainage in eastern North Carolina and the history of drainage in the region can help improve regional water resources management and policy approaches in the $21^{\text {st }}$ century.

Acknowledgments: Many thanks to Charles Humphrey, Marcelo Ardon, and Alex Manda at East Carolina University for providing helpful reviews of an earlier draft. I am grateful for earlier discussions on the topic and insights from Dr. Mark Brinson and Dr. Stan Riggs. In addition, Mr. Charles Vandiford of the Southeast Drainage Commission provided helpful advice on the availability of drainage data and the history of agricultural drainage in the region.

\section{LITERATURE CITED}

ARDON, M., J. L. MORSE, M. W. DOYLE, AND E. S. BERNHARDT. 2010. The water quality consequences of restoring wetland hydrology to a large agricultural watershed in the Southeastern Coastal Plain. Ecosystems 13:1060-1078.

BEAUCHAMP, K. H. 1987. A history of drainage and drainage methods. Pp. 13-29 in: Pavelis, G. A. (ed.), Farm Drainage in the United States: History, Status, and Prospects. Economic Research Service, U.S. Dept. Agricult. Miscell. Publ. No. 1455. U.S. Government Print. Off., Wash., DC.

BIRGAND, F., R. W. SKAGGS, G. M. CHESCHEIR, AND J. W. GILLIAM. 2007. Nitrogen removal in streams of agricultural
catchments-A literature review. Critical Rev. Env. Sci. Tech. 37(5):381-487.

BLANN, K. L., J. L. ANDERSON, G. R. SANDS, AND B. VONDRACEK. 2009. Effects of agricultural drainage on aquatic ecosystems: A review. Critical Rev. Env. Sci. Tech. 39(11):909-1001.

BOYLES, R., C. HOLDER, AND S. RAMAN. 2004. North Carolina Climate: A summary of climate normals and averages at 18 agricultural research stations. Tech. Bull. 322, Nor. Car. Agricul. Res. Serv., Raleigh, NC.

BRINSON, M. M., AND S. D. ECKLES. 2011. U.S. Department of Agriculture conservation program and practice effects on wetland ecosystem services: a synthesis. Ecol. Applic. 21(3):S116-S127.

BROOKES, A. 1988. Channelized Rivers-Perspectives for Environmental Management. John Wiley Sons, Chichester, U.K. 326 pp.

CASHIN, G., J. DORNEY, AND C. RICHARDSON. 1992. Wetland alteration trends on the North Carolina Coastal Plain. Wetlands 12(2):63-71.

CHRISTIANSON, L. E., A. BHANDARI, AND M. J. HELMERS. 2011. Pilot-scale evaluation of denitrification drainage bioreactors: Reactor geometry and performance. J. Environment. Eng. 137(4):213-220.

COOPER, S. R., S. K. MCGLOTHLIN, M. MADRITCH, AND D. L. JONES. 2004. Paleoecological evidence of human impacts on the Neuse and Pamlico Estuaries of North Carolina, USA. Estuaries 27:617-635.

DEAL, S. C., J. W. GILliAM, R. W. SKAGGS, AND K. D. KONYHA. 1986. Prediction of nitrogen and phosphorus losses as related to agricultural drainage system design. Agricult. Ecosys. Environ. 18:37-51.

DODDS, W. K., W. W. BOUSKA, J. L. EITZMANN, T. J. PILGER, K. L. PITS, A. J. RILEY, J. T. SCHOESSER, AND D. J. THORNBRUGH. 2009. Eutrophication of U.S. freshwaters: Analysis of potential economic damages. Environ. Sci. Tech. 43(1):12-19.

DOTY, C. W., J. E. PARSONS, A. NASSEHZADEH-TABRIZI, R. W. SKAGGS, AND A. W. BADR. 1982. Deep ditch overdrainage affects water table depth and crop yields. Proceedings of the Specialty Conference on Environmentally Sound Water and Soil Management ASCE, Orlando, FL. 113-121.

DUKES, M. D., AND R. O. EVANS. 2006. Impact of agriculture on water quality in the North Carolina Middle Coastal Plain. J. Irrigation Drainage Engineer. 132(3):250-262.

DUKES, M. D., R. O. EVANS, J. W. GILliAM, AND S. H. KUNICKIS. 2003. Interactive effects of controlled drainage and riparian buffers on shallow groundwater quality. J. Irrigation Drainage Engineer. 129(2):82-92.

ENSIGN, S. H., S. K. MCMILLAN, S. P. THOMPSON, AND M. F. PIEHLER. 2006. Nitrogen and phosphorus attenuation within the stream network of a coastal, agricultural watershed. J. Environment. Quality 35:1237-1247.

EPA (U.S. ENVIRONMENTAL PROTECTION AGENCY). 2010. Pesticides: Reregistration-Aldicarb Factsheet. http://www.epa.gov/ oppsrrd1/REDs/factsheets/aldicarb_fs.html accessed on 7/29/11

EVANS, R. O., W. R. SKAGGS, AND J. W. GILLIAM. 1995. Controlled versus conventional drainage effects on water quality. J. Irrigation Drainage Engineer. 121(4):271-276.

EVANS, R. O., K. L. BASS, M. R. BURCHELL, R. D. HINSON, R. JOHNSON, AND M. DOXEY. 2007. Management alternatives to enhance water quality and ecological function of channelized streams and drainage canals. J. Soil Water Conserv. 62(4): 308-320.

EVANS, R. O., J. E. PARSONS, K. STONE, AND W. B. WELLS. 1992. Water table management on a watershed scale. J. Soil Water Conserv. 47(1):58-64. 
FAUSEY, N. R., E. J. DOERING, AND M. L. PALMER. 1987. Purposes and benefits of drainage. Chapter 4. Pp. 48-51 in: Pavelis, G. A. (ed.), 1987. Farm drainage in the United States: History, status, and prospects. Economic Research Service, U.S. Department of Agriculture. Miscellaneous Publication No. 1455. U.S. Government Printing Office, Washington, DC. 186 pp.

FAUSEY, N. R., L. C. BROWN, H. W. BELCHER, AND R. S. KANWAR. 1995. Drainage and water quality in Great Lakes and Cornbelt States. J. Irrigation Drainage Engineer. 121(4):283-288.

GILLIAM, J. W., AND R. W. SKAGGS. 1986. Controlled agricultural drainage to maintain water quality. J. Irrigation Drainage Engineer. 112(3):254-263.

HARDEN, S. L., AND T. B. SPRUILL. 2004. Ionic composition and nitrate in drainage water from fields fertilized with different nitrogen sources, Middle Swamp watershed, North Carolina, August 2000-August 2001. U.S. Geol. Surv. Sci. Invest. Rept. 2004-5123, USGS, Reston, VA. 20 pp.

HARDEN, S. L., AND T. B. SPRUILL. 2008. Factors affecting nitrate delivery to streams from shallow ground water in the North Carolina Coastal Plain. U.S. Geol. Surv. Sci. Invest. Rept. 2008-5021, USGS, Reston, VA. 39 pp.

HARDISON, E. C., M. A. O'DRISCOLL, J. P. DELOATCH, R. J. HOWARD, AND M. M. BRINSON. 2009. Urban land-use, channel incision, and riparian water table decline along Inner Coastal Plain streams, North Carolina. J. Amer. Water Resources Assoc. 45(4):1032-1046.

HARNED, D. A., G. MCMAHON, T. B. SPRUILL, AND M. B. WOODSIDE. 1995. Water-quality assessment of the Albemarle-Pamlico drainage basin, North Carolina and VirginiaCharacterization of suspended sediment, nutrients, and pesticides. U.S. Geol. Surv. Open-File Rept. 95-191. USGS, Reston, VA. $131 \mathrm{pp}$.

HEATH, R. C. 1975. Hydrology of the Albemarle-Pamlico Region, North Carolina: A Preliminary Report on the Impact of Agricultural Developments. U.S. Geol. Surv. Water Resour. Invest. 9-75. USGS, Raleigh, NC. 89 pp.

HENMAN, J., AND B. POULTER. 2008. Inundation of freshwater peatlands by sea level rise: Uncertainty and potential carbon cycle feedbacks. J. Geophysical Res. 113(G01011):1-11.

HERRITAGE, J. 1920. Relation of drainage projects to malaria control. Southern Medical J. 13(6):424-426.

HUPP, C. R. 2000. Hydrology, geomorphology and vegetation of Coastal Plain rivers in the south-eastern USA. Hydrological Processes 14:2991-3010.

JAYNES, D., AND D. JAMES. 2007. The Extent of Farm Drainage in the United States. Proceedings Annual Meeting of the Soil and Water Conservation Society, Saddlebrook Resort, Tampa, Florida, 21 July 2007. Accessed on 6 September 2011 at: http://www.ars.usda.gov/SP2UserFiles/Place/36251500/TheExtentof FarmDrainageintheUnitedStates.pdf

KERR, W. C. 1875. A report on the sanitary relations of drainage and water-supply in North Carolina and the south Atlantic states, as affected by topographical and geological conditions. Amer. Assoc. Public Health, Rept. Papers 2:348-356.

KLADIVKO, E. J., L. C. BROWN, AND J. L. BAKER. 2001. Pesticide transport to subsurface tile drains in humid regions of North America. Critical Rev. Env. Sci. Tech. 31(1):1-62.

KONYHA, K. D., R. W. SKAGGS, and J. W. GILliAM. 1992. Effects of drainage and water management practices on hydrology. J. Irrigation Drainage Engineer. 118:807-819.

KUENZLER, E. J., P. J. MULHOLLAND, L. A. RULEY, AND R. P. SNIFFEN. 1977. Water quality of North Carolina Coastal Plain streams and effects of channelization. North Carolina Water Resources Res. Inst. Rept. 77-127, Raleigh, NC. 178 pp.
LECCE, S. A., P. P. PEASE, P. A. GARES, AND J. WANG. 2006 Seasonal controls on sediment delivery in a small coastal plain watershed, North Carolina, USA. Geomorphology 73:246-260.

LEIBOWITZ, S. G., P. J. WIGINGTON, J. R. M.C. RAINS, AND D. M. DOWNING. 2008. Non-navigable streams and adjacent wetlands: addressing science needs following the Supreme Court's Rapanos decision. Frontiers Ecol. Environ. 6:364-371.

LILLY, J. P. 1981. A history of swamp land development in North Carolina. Pp. 20-39 in: Richardson, C. J. (ed.), Pocosin Wetlands-An Integrated Analysis of Coastal Plain Freshwater Bogs. Hutchinson Ross Publishing Co. Stroudsburg, PA.

MALLIN, M., AND L. CAHOON. 2003. Industrialized animal production-A major source of nutrient and microbial pollution to aquatic ecosystems. Population Environ. 24(5):369-385.

MASON, R. R. JR., C. E. SIMMONS, AND S. A. WATKINS. 1990. Effects of channel modifications on the hydrology of Chicod Creek Basin, North Carolina, 1975-1987. USGS WaterResources Investigations Rept. 90-4031. USGS, Raleigh, NC. $83 \mathrm{pp}$.

MCMAHON, G., AND D. A. HARNED. 1998. Effect of environmental setting on sediment, nitrogen, and phosphorus concentrations in Albemarle-Pamlico Drainage Basin, North Carolina and Virginia, USA. Environ. Mgt. 22(6):887-903.

MCMILLAN, S. K., M. F. PIEHLER, S. P. THOMPSON, AND H. W. PAERL. 2010. Denitrification of nitrogen released from senescing algal biomass in coastal agricultural headwater streams. J. of Environment. Quality 39:274-281.

MUNSTER, C. L., R. W. SKAGGS, J. E. PARSONS, R. O. EVANS, J. W. GILLIAM, AND E. W. HARMSEN. 1995. Aldicarb transport in drained coastal plain soil. J. Irrigation Drainage Engineer. 121(6):378-384.

NCDENR. 2004, Basinwide Planning Program: 2004 Tar-Pamlico River Basinwide Water Quality Plan. Division of Water Quality, Water Quality Section, Environmental Sciences Branch, Raleigh, North Carolina. 320 pp.

NC DENR. 2011. North Carolina TMDLs Webpage. Accessed 6 September 2011 at: http://portal.ncdenr.org/web/wq/ps/mtu/ tmdl

NEEDELMAN, B. A., P. J. KLEINMAN, A. L. ALlEN, AND J. S. STROCK. 2007. Managing agricultural drainage ditches for water quality protection. J. Soil Water Cons. 62(4):171-178.

O'DRISCOLL, M., J. SOBAN, AND S. LECCE. 2009. Stream channel enlargement response to urban land cover in small Coastal Plain watersheds, North Carolina. Physical Geog. 30(6): $528-555$.

OPIS. 2011. Pitt County Online Parcel Information System. Accessed on 1 September 2011 at: http://gis2.pittcountync.gov/opis/

PAERL, H. W., L. M. VALDES, AND M. F. PIEHLER. 2006. Assessing the effects of nutrient management in an estuary experiencing climatic change: The Neuse River Estuary, North Carolina. Environ. Mgt. 37(3):422-436.

PAVELIS, G. A., ed. 1987. Farm drainage in the United States: History, status, and prospects. Economic Research Service, U.S. Department of Agriculture. Miscellaneous Publication No. 1455. U.S. Government Printing Office, Washington, DC. 186 pp.

PENN, C. J., R. B. BRYANT, P. J. A. KLEINMAN, AND A. L. ALLEN. 2007. Sequestering dissolved phosphorus from ditch drainage water. J. Soil Water Cons. 62(4):269-276.

POWELL, G. E., A. D. WARD, D. E. MECKLENBURG, AND A. D. JAYAKARAN. 2007a. Two-stage channel systems: Part 1. A practical approach for sizing agricultural ditches. J. Soil Water Cons. 62(4):277-286.

POWELL, G. E., A. D. WARD, D. E. MECKLENBURG, J. DRAPER, AND W. WORD. 2007b. Two-stage channel systems: Part 2. Case studies. J. Soil Water Cons. 62(4):286-296. 
PRATT, J. H. 1908. Proceedings of drainage convention held at New Bern, North Carolina, 9 September 1908. No. Car. Geol. and Econ. Surv., Raleigh, NC. 94 pp.

PRATT, J. H. 1909. Proceedings of the second annual drainage convention held at New Bern, North Carolina, 11 November and 12 1909. No. Car. Geol. and Econ. Surv., Raleigh, NC. 50 pp.

PUCKETT, L. J. 2004. Hydrogeologic controls on the transport and fate of nitrate in ground water beneath riparian buffer zones: results from thirteen studies across the United States. Water Sci. Tech. 49(3):47-53.

RICHARDSON, C. J. 2003. Pocosins: Hydrologically isolated or integrated wetlands on the landscape. Wetlands 23(3):563-576.

ROSS, J. R. 1973. Conservation and Economy: The North Carolina Geological Survey (1891-1920). Forest History 16(4):20-27.

RUFFIN, E. 1861. Agricultural, Geological, and Descriptive Sketches of Lower North Carolina and the Similar Adjacent Lands. Rept. to Governor J. Ellis, Raleigh, NC. 296 pp.

SIMON, A. 1989. A model of channel response in disturbed alluvial channels. Earth Surface Processes Landforms 14:11-26.

SKAGGS, R. W., A. NASSEHZADEH-TABRIZI, AND G. R. FOSTER. 1982. Subsurface drainage effects on erosion. J. Soil Water Cons. 37(3):167-172.

SKAGGS, R. W., M. A. BREVE, and J. W. GILliAM. 1994. Hydrologic and water quality impacts of agricultural drainage. Critical Rev. Env. Sci. Tech. 24:1-32.

SKAGGS, R. W., M. A. YOUSSEF, AND G. M. CHESCHEIR. 2006. Drainage design coefficients for eastern United States. Agricultural Water Mgt. 86:40-49.

SMITH, D. R., AND E. A. PAPPAS. 2007. Effect of ditch dredging on the fate of nutrients in deep drainage ditches of the Midwestern United States. J. Soil Water Cons. 62(4):252-261.

SPRUILL, T. B. 2004. Effectiveness of riparian buffers in controlling ground-water discharge of nitrate to streams in selected hydrogeologic settings of the North Carolina Coastal Plain. Water Sci. Tech. 49(3):63-70.

SPRUILL, T. B., D. A. HARNED, P. M. RUHL, G. MCMAHON, K. E. SMITH, D. R. GALEONE, AND M. D. WOODSIDE. 1998. Water quality in the Albemarle-Pamlico drainage basin, North Carolina and Virginia, 1992-1995. U.S. Geol. Surv. Circular 1157. USGS Information Services, Denver, CO. 36 pp.

STONE, K. C., R. C. SOMMERS, G. H. WILliAMS, AND D. E. HAWKINS. 1995. Water table management in the eastern Coastal Plain. J. Soil Water Cons. 47(1):47-51.

STOW, C. A., M. E. BORSUK, AND D. W. STANLEY. 2001. Long-term changes in watershed nutrient inputs and riverine exports in the Neuse River, North Carolina. Water Res. 35(6):1489-1499.

STROCK, J. S., P. J. A. KLEINMAN, K. W. KING, AND J. A. DELGADO. 2010. Drainage water management for water quality protection. J. Soil Water Cons. 65(6):131A-136A.

SUN, G., S. G. MCNULTY, D. M. AMATYA, R. W. SKAGGS, L. W. SWIFT, J. P. SHEPARD, AND H. RIEKERK. 2002. A comparison of the watershed hydrology of coastal forested wetlands and the mountainous uplands in the southern U.S. J. Hydrology, 263:92-104.

SWEET, W., AND J. GERATZ. 2003. Bankfull hydraulic geometry relationships and recurrence intervals for North Carolina's Coastal Plain. J. Amer. Water Res. Assoc. 39:861-871.

TATUM, S. 1910. Reclamation and drainage. Annals of the American Academy of Political and Social Science 35(1):77-80.

TESORIERO, A. J., T. B. SPRUILL, AND J. L. EIMERS. 2004. Geochemistry of shallow ground water in coastal plain environments in the southeastern United States: implications for aquifer susceptibility. Applied Geochem. 19:14711482.

U.S. BUREAU OF THE CENSUS. 1922, Fourteenth Census of the United States Taken in the Year 1920: Vol. VII-Irrigation and Drainage, Washington, DC, U.S. 741 pp. Govt. Print. Off.

U.S. BUREAU OF THE CENSUS. 1932, Fifteenth Census of the United States: 1930. Drainage of Agricultural Lands, Washington, DC, U.S. 453 pp. Govt. Print. Off.

U.S. BUREAU OF THE CENSUS. 1942, Sixteenth Census of the United States: 1940. Drainage of Agricultural Lands, Washington, DC, U.S. 683 pp Govt. Print. Off.

U.S. BUREAU OF THE CENSUS. 1952, U.S. Census of Agriculture: 1950. Drainage of Agricultural Lands, Washington, DC, U.S. 307 pp. Govt. Print. Off.

U.S. BUREAU OF THE CENSUS. 1961, U.S. Census of Agriculture: 1959. Final Report. Volume 4, United States drainage of agricultural lands: drainage projects, size, type, area served, cost, works, Washington, DC, U.S. 364 pp. Govt. Print. Off.

U.S. BUREAU OF THE CENSUS. 1973, Census of Agriculture, 1969: Volume VI-Drainage of Agricultural Lands. Washington, DC, U.S. 207 pp. Govt. Print. Off.

U.S. BUREAU OF THE CENSUS. 1980, 1978 Census of Agriculture. Volume 5-Special Reports; Part 5. Drainage of Agricultural Lands AC78-SR-5. USDA, Washington, DC. 79 pp.

U.S. BUREAU OF THE CENSUS. 2007, US Census Governments Integrated Directory. Accessed on 1 September 2011 at: http:// harvester.census.gov/gid/gid_07/options.html

USDA. 1997. Agricultural Resources and Environmental Indicators, 1996-1997. U.S. Department of Agriculture, Economic Research Service, Natural Resources and Environment Division. Agricultural Handbook No. 712, Washington DC. $327 \mathrm{pp}$.

WARREN, G. F. 1998. Spectacular increases in crop yields in the United States in the Twentieth Century. Weed Technol. 12:752-760.

WHITALL, D., B. HENDRICKSON, AND H. PAERL. 2003. Importance of atmospherically deposited nitrogen to the annual nitrogen budget of the Neuse River Estuary, NC. Environ. Internat. 29:393-399.

WILLIAMS, J. B., AND J. E. I. PINDER. 1990. Ground-water flow and runoff in a Coastal Plain stream. Water Resources Bull. 26:343-351.

WINNER, M. D. J. R., AND R. W. COBLE. 1996. Hydrogeologic framework of the North Carolina Coastal Plain: regional aquifer-system analysis northern Atlantic Coastal Plain. US Geol. Surv. Prof. Pap. 1404-I 106.

WINNER, M. D., JR., AND C. E. SIMMONS. 1977. Hydrology of the Creeping Swamp Watershed, NC, with reference to potential effects of stream channelization. U.S. Geological Survey Water Resources Invest. 77-26. U.S. Geologic Survey, Raleigh, NC. $54 \mathrm{pp}$.

WOODSIDE, M. D., AND K. E. RUHL. 2001. Pesticides in Streams in the Tar-Pamlico Drainage Basin, North Carolina, 1992-1994. U.S. Geological Survey Water-Resources Invest. Rept. 01-4067, Raleigh, NC. 20 pp.

WOSSINK, G. A., AND D. L. OSMOND. 2002. Farm economics to support the design of cost-effective Best Management Practice (BMP) programs to improve water quality: Nitrogen control in the Neuse River Basin, North Carolina. J. Soil Water Cons. 57(4):213-220. 